\title{
ANALISIS TERHADAP KONTROVERSI RANCANGAN PERATURAN PEMERINTAH TENTANG TATA CARA INTERSEPSI YANG SESUAI HUKUM (LAWFUL INTERCEPTION)
}

\author{
Edmon Makarim ${ }^{1}$
}

Interception can be translated to all measures to intercept or obtain the information either in oral or electronic form, either in the form of online and offline. In other words interception or wiretap is actually an attempt to do a search and seizure to access and obtain information that is communicated by the parties. In the development, provision of technical standards is referring to the European intercept Technical Standards Institute ('ETSI') and also the American National Standards Institute ("ANSI"). Need to be observed that prior to the UUITE, the process of tapping an legal umbrella to the provisions in the Telecommunications Act. However, the paradigm of "tapping" with "recording" information is actually two different things.

Kata kunci: intersepsi, UUITE, rancangan peraturan pemerintah

\section{Latar Belakang}

Baru-baru ini masyarakat dihadapkan pada kontroversi pendapat tentang perlu tidaknya suatu Rancangan Peraturan Pemerintah tentang Intersepsi. Sangat disyukuri bahwa perbedaan pendapat selayaknya akan memberikan pengkayaan wacana yang lebih mendalam untuk melihat ketentuan hukum yang semestinya terhadap proses intersepsi untuk kepentingan penegakan hukum. Namun tampaknya perbedaan pendapat tersebut kurang berimbang ditampilkan kepada publik, sehingga dikhawatirkan akan cenderung dapat menyesatkan publik sekiranya pendapat yang berkembang ternyata tidak dibangun dari suatu pemahaman yang cukup sehingga luput mengkaji bagaimana kaedah hukum yang semestinya terhadap tindakan intersepsi itu. Oleh karena itu, penulis memandang perlu untuk mencermati beberapa opini yang tengah berkembang dan mengkajinya dalam penulisan ini.

1 Dosen Inti Penelitian bidang Hukum Telematika FHUI. Alamt korespondensi: edmon_makarim@yahoo.com 
Pembicaraan tentang intersepsi, sebenarnya bukan hal baru karena pernah terjadi pada beberapa waktu lalu, setidaknya pada sekitar tahun 1990 an yakni pada saat dirumuskannya penyadapan untuk kepentingan penanggulangan tindak pidana psikotropika dalam UU No.5 tahun 1997 tentang Psikotropika ("UU Psikotropika"), ${ }^{2}$ UU No.22 Tahun 1997 tentang Narkotika ("UU Narkotika"), ${ }^{3}$ UU No.31 Tahun 1999 tentang Pemberantasan Tindak Pidana Korupsi ("UU Tipikor"), ${ }^{4}$ dan revisi terhadap UU No.3 Tahun 1989 tentang Telekomunikasi menjadi UU No.36 Tahun 1999 ("UU Telekomunikasi"), ${ }^{5}$ dimana pengaturan tentang penyadapan adalah salah satu

${ }^{2}$ Pasal 55 UU Psikotropika menyatakan bahwa selain yang ditentukan dalam Undangundang Nomor 8 Tahun 1981 tentang Hukum Acara Pidana (Lembaran Negara Tahun 1981 Nomor 76, Tambahan Lembaran Negara Nomor 3209), penyidik polisi negara Republik Indonesia dapat: (a). melakukan teknik penyidikan penyerahan yang diawasi dan teknik pembelian terselubung; (b). membuka atau memeriksa setiap barang kiriman melalui pos atau alat-alat perhubungan lainnya yang diduga mempunyai hubungan dengan perkara yang menyangkut psikotropika yang sedang dalam penyidikan; dan (c) menyadap pembicaraan melalui telepon dan/atau alat telekomunikasi elektronika lainnya yang dilakukan oleh orang yang dicurigai atau diduga keras membicarakan masalah yang berhubungan dengan tindak pidana psikotropika. Jangka waktu penyadapan berlangsung untuk paling lama 30 (tiga puluh) hari. Dalam penjelasannya dinyatakan bahwa Pélaksanaan teknik penyidikan penyerahan yang diawasi dan teknik pembelian terselubung serta penyadapan pembicaraan melalui telepon dan/atau alat-alat telekomunikasi elektronika lainnya hanya dapat dilakukan atas perintah tertulis Kepala Kepolisian Republik Indonesia atau pejabat yang ditunjuknya.

${ }^{3}$ Pasal 66 Ayat (2) Undang-Undang Nomor 22 Tahun 1997 tentang Narkotika menyatakan bahwa Penyidik Pejabat Polisi Negara Republik Indonesia yang diberi tugas melakukan penyelidikan dan penyidikan tindak pidana narkotika, berwenang untuk menyadap pembicaraan melalui telepon atau alat telekomunikasi lain yang dilakukan oleh orang yang diduga keras membicarakan masalah yang berhubungan dengan tindak pidana narkotika. Dan dalam ayat (3) dinyatakan bahwa (3) Tindakan penyadapan sebagaimana dimaksud dalam ayat (2) berlangsung untuk jangka waktu paling lama 30 (tiga puluh) hari. Selanjutnya UU ini direvisi dengan kelahiran UU No.35 Tahun 2009 tentang Narkotika.

${ }^{4}$ Dalam penjelasan pasal 26 dinyatakan bahwa Kewenangan penyidik dalam Pasal ini termasuk wewenang untuk melakukan penyadapan (wiretaping).

${ }^{5}$ Pasal 40 UU telekomunikasi menyatakan bahwa Setiap orang dilarang melakukan kegiatan penyadapan atas informasi yang disalurkan melalui jaringan telekomunikasi dalam bentuk apapun. Dalam penjelasannya dinyatakan bahwa Yang dimaksud dengan penyadapan dalam pasal ini adalah kegiatan memasang alat atau perangkat tambahan pada jaringan telekomunikasi untuk tujuan mendapatkan informasi dengan cara tidak sah. Pada dasarnya informasi yang dimiliki oleh seseorang adalah hak pribadi yang harus dilindungi sehingga penyadapan harus dilarang. Kemudian dalam pasal 42 ayat (2) dinyatakan bahwa Untuk keperluan proses peradilan pidana, penyelenggara jasa telekomunikasi dapat merekam informasi yang dikirim dan/atau diterima oleh penyelenggara jasa telekomunikasi serta dapat memberikan informasi yang diperlukan atas: (a). permintaan tertulis Jaksa Agung dan/atau 
isu yang cukup penting karena dapat melanggar kerahasiaan berita dalam berkomunikasi.

Kemudian pada tahun 2002 dengan lahirnya UU No.30 Tahun 2002 tentang Komisi Pemberantasan Tindak Pidana Korupsi ("UU-KPK") yang diberikan kewenangan Penyadapan dan Perekaman, dan juga pada aaat dibuatnya PERPU Nomor 1 Tahun 2002

Tentang Pemberantasan Tindak Pidana Terorisme ("UU-Terorisme") yang memberikan kewenangan penyadapan pada penyidik. Selanjutnya, juga terjadi pada tahun 2003 dimana pada pembahasan UU No.18 Tahun 2003 tentang Advokat ("UU Advokat"), ${ }^{7}$ para advokat meminta kekebalan (immunity) untuk tidak disadap. Berikutnya pada tahun 2007 dengan UU Nomor 21 Tahun 2007 tentang Pemberantasan Tindak Pidana Perdagangan Orang ("UU Perdagangan Orang"), yang juga memberikan kewenangan penyidik untuk melakukan penyadapan.

Kepala Kepolisian Republik Indonesia untuk tindak pidana tertentu; (b) permintaan penyidik untuk tindak pidana tertentu sesuai dengan Undang-undang yang berlaku. Dalam penjelasannya dinyatakan bahwa Yang dimaksud dengan proses peradilan pidana dalam ketentuan ini mencakup penyidikan, penuntutan, dan penyidangan. Selanjutnya dalam ayat (3) dinyatakan bahwa ketentuan mengenai tata cara permintaan dan pemberian rekaman informasi sebagaimana dimaksud pada ayat (2) diatur dengan Peraturan Pemerintah.

${ }^{6}$ Pasal 31 ayat (1) menyatakan bahwa Berdasarkan bukti permulaan yang cukup sebagaimana dimaksud dalam Pasal 26 ayat (4), penyidik berhak: (a). membuka, memeriksa, dan menyita surat dan kiriman melalui pos atau jasa pengiriman lainnya yang mempunyai hubungan dengan perkara tindak pidana terorisme yang sedang diperiksa; (b) menyadap pembicaraan melalui telepon atau alat komunikasi lain yang diduga digunakan untuk mempersiapkan, merencanakan, dan melakukan tindak pidana terorisme. Selanjutnya pada pasal 31 ayat (2) dinyatakan bahwa Tindakan penyadapan sebagaimana dimaksud dalam ayat (1) huruf b, hanya dapat dilakukan atas perintah Ketua Pengadilan Negeri untuk jangka waktu paling lama 1 (satu) tahun. dan pada ayat (3) dinyatakan bahwa Tindakan sebagaimana dimaksud dalam ayat (1) dan ayat (2) harus dilaporkan atau dipertanggungjawabkan kepada atasan penyidik.

${ }^{7}$ Pasal 19 ayat (2) UU No.18 Tahun 2003 tentang Advokat yang menyatakan bahwa Advokat berhak atas kerahasiaan hubungannya dengan Klien, termasuk perlindungan atas berkas dan dokumennya terhadap penyitaan atau pemeriksaan dan perlindungan terhadap penyadapan atas komunikasi elektronik Advokat.

${ }^{8}$ Pasal 31 UU Tindak Pidana Perdagangan Orang, pada ayat (1) menyatakan bahwa berdasarkan bukti permulaan yang cukup penyidik berwenang menyadap telepon atau alat komunikasi lain yang diduga digunakan untuk mempersiapkan, merencanakan, dan melakukan tindak pidana perdagangan orang, dan pada ayat (2) menyatakan bahwa Tindakan penyadapan sebagaimana dimaksud pada ayat (1), hanya dilakukan atas izin tertulis ketua pengadilan untuk jangka waktu paling lama 1 (satu) tahun. 
Terkait dengan itu pula, pada tahun 2003 dan tahun 2006 yakni pada saat adanya pengajuan judicial review kepada Mahkamah Konstitusi terhadap pasal 12 ayat (1) huruf (a) UU No.30 Tahun 2002 tentang Komisi Pemberantasan Tindak Pidana Korupsi ("UU-KPK"), ${ }^{9}$ khususnya tentang kewenangan penyadapan yang karena tidak ada ketentuan formil pelaksanaannya dikhawatirkan berpotensi melanggar hak konstitusional setiap warga negara, bahkan pada suatu kasus tertentu diduga telah memberikan sarana kepada KPK untuk mempersiapkan suatu pola yang mengarah pada penjebakan dimana KPK sebagai pihak yang telah memperoleh informasi dari hasil penyadapan, dapat menstimulasi pihakpihak lain untuk mengarahkan Pemohon pada tindak pidana yang telah ditargetkan sebelumnya. Selanjutnya Mahkamah Konstitusi dengan Putusan Nomor 006/PUU-I/2003, ${ }^{10}$ dan Nomor 012-016-019/PUU-IV/2006 memberikan amanat untuk melakukan perubahan terhadap UU KPK atau mengatur tatacara intersepsi dalam peraturan perundang-undangan tersendiri.

\section{1. bahwa Putusan Mahkamah Konstitusi Nomor} 006/PUU-I/2003, sebagaimana disebutkan di atas, dalam pertimbangan hukumnya pada waktu memutus permohonan pengujian.Pasal 12 Ayat (1) huruf a UU KPK telah menyatakan, antara lain, “... untuk mencegah kemungkinan penyalahgunaan kewenangan untuk penyadapan dan perekaman Mahkamah Konstitusi berpendapat perlu ditetapkan perangkat peraturan yang mengatur syarat dan tata cara penyadapan dan perekaman dimaksud". Pertimbangan

${ }^{9}$ Pasal 12 ayat (1) huruf (a): Dalam melaksanakan tugas penyelidikan, penyidikan, dan penuntutan sebagaimana dimaksud dalam Pasal 16 huruf e Komisi Pemberantasan Tindak Pidana Korupsi berwenang melakukan penyadapan dan perekaman pembicaraan

10 Dalam putusan Perkara Nomor 006/PUU-I/2003 hal. 104: "untuk mencegah kemungkinan penyalahgunaan kewenangan untuk penyadapan dan perekaman Mahkamah Konstitusi berpendapat perlu ditetapkan perangkat peraturan yang mengatur syarat dan tata cara penyadapan dan perekaman dimaksud." kemudian dalam dissenting opinion oleh Hakim Konstitusi Maruarar Siahaan, S.H, pada hal 116-117: "Kehadiran sebagai super body, yang dengan kewenangan yang luar biasa, dapat diberikan wewenang perekaman percakapan melalui telepon orang-orang yang disangka korupsi tetapi harus dengan pengawasan yang jelas dalam peraturan perundang-undangan yang mengatur syarat-syarat minimal yang harus dipenuhi sedemikian rupa, sehingga tidak menimbulkan kesewenang-wenangan. Meskipun hal ini dipandang sebagai ancaman terhadap hak asasi manusia, hemat kami tentang ini cukup direkomendasikan adanya Peraturan Pemerintah yang lebih jelas memberi batasan dan syaratsyarat juridis terhadap kewenangan yang luar biasa tersebut.". 
hukum Mahkamah tersebut adalah sesuai dengan bunyi ketentuan Pasal 32 Undang-Undang Nomor 39 Tahun 1999 tentang Hak Asasi Manusia yang menyatakan, "Kemerdekaan dan rahasia dalam hubungan surat-menyurat termasuk hubungan komunikasi melalui sarana elektronik tidak boleh diganggu, kecuali atas perintah hakim atau kekuasaan lain yang sah sesuai dengan ketentuan peraturan perundang-undangan." Mahkamah memandang perlu untuk mengingatkan kembali bunyi pertimbangan hukum Mahkamah dalam Putusan Nomor 006/PUUI/2003 tersebut oleh karena penyadapan dan perekaman pembicaraan merupakan pembatasan terhadap hak-hak asasi manusia, di mana pembatasan demikian hanya dapat dilakukan dengan undangundang, sebagaimana ditentukan oleh Pasal 28J Ayat (2) UUD 1945. Undang-undang dimaksud itulah yang selanjutnya harus merumuskan, antara lain, siapa yang berwenang mengeluarkan perintah penyadapan dan perekaman pembicaraan dan apakah perintah penyadapan dan perekaman pembicaraan itu baru dapat dikeluarkan setelah diperoleh bukti permulaan yang cukup, yang berarti bahwa penyadapan dan perekaman pembicaraan itu untuk menyempurnakan alat bukti, ataukah justru penyadapan dan perekaman pembicaraan itu sudah dapat dilakukan untuk mencari bukti permulaan yang cukup. Sesuai dengan perintah Pasal 28J Ayat (2) UUD 1945, semua itu harus diatur dengan undang-undang guna menghindari penyalahgunaan wewenang yang melanggar hak asasi;

2. bahwa berdasarkan seluruh uraian di atas, dan setelah membaca dalil-dalil yang diajukan oleh Pemohon dalam hubungannya dengan permohonan pengujian Pasal 12 Ayat (1) huruf a UU KPK, telah ternyata tidak terdapat "alasan konstitusional yang berbeda" dalam dalil-dalil Pemohon dimaksud, sehingga permohonan Pemohon mengenai inkonstitusionalitas Pasal 12 Ayat (1) huruf a UU KPK adalah tidak beralasan;

3. bahwa meskipun permohonan Pemohon tidak cukup beralasan, tetapi karena Pasal 12 Ayat (1) huruf a UU 


\begin{abstract}
KPK menyangkut pembatasan HAM, maka sesuai dengan Pasal 28J Ayat (2) UUD 1945, syarat-syarat dan tata cara tentang penyadapan tersebut harus ditetapkan dengan undang-undang, apakah dalam UU KPK yang diperbaiki atau dalam undang-unidang lain;
\end{abstract}

Isu legalitas dari proses penyadapan kembali menjadi hangat kembali setelah terjadinya pemutaran hasil penyadapan di mahkamah konstitusi tahun lalu terkait dengan permohononan uji konstitusi oleh Chandra Hamzah dan Bibit Samad Riyanto terhadap keberadaan pasal 32 ayat (1) butir c UU KPK yang menyatakan bahwa dalam hal Pimpinan Komisi Pemberantasan Korupsi menjadi tersangka tindak pidana kejahatan, diberhentikan sementara dari jabatannya.

Dengan didukung oleh suatu gerakan komunikasi masa "Cicak vs Buaya"11 yang mencium adanya dugaan rekayasa kasus terhadap pimpinan KPK, maka untuk melindungi eksistensi pimpinan KPK agar tidak diintervensi oleh pemerintah, pemohon meminta Majelis Hakim Konstitusi untuk memperkenankan pimpinan KPK memutarkan hasil penyadapan di sidang mahkamah konstitusi demi untuk memperlihatkan adanya dugaan suatu konspirasi besar untuk menjatuhkan KPK dengan cara menjadikannya tersangka. Kemudian, Ketua Mahkamah Konsitusi mengabulkan permohonan tersebut dan memandang perlu untuk memutarkannya di hadapan publik dengan durasi yang cukup panjang berikut percakapan yang diduga sebagai makelar kasus dan percakapan dengan pengacaranya. Namun juga sangat menarik untuk dicermati bahwa pada faktanya, sebelum pemutaran tersebut dilakukan didalam persidangan, sebenarnya telah beredar transkrip hasil sadapan tersebut kepada publik, khususnya yang ditampilkan oleh beberapa media cetak ternama. Dalam percakapan tersebut diputarkan juga percakapan seseorang yang diduga menjadi perekayasa kasus dengan pihak pengacaranya, sementara terhadap profesi pengacara sesungguhnya telah mempunyai kekebalan (immunity) untuk tidak boleh disadap. Sempat menjadi perdebatan apakah pemutaran pembicaraan tersebut telah dilakukan sebagaimanamestinya?.

${ }^{11}$ Gerakan masa ini lahir akibat kutipan suatu media masa yang menggarisbawahi pernyataan Komjen Susno Duadji Kepala Badan Reserse dan Kriminal ("Kabareskrim") POLRI pada saat itu, yang membandingkan kemampuan alat sadap yang dimiliki oleh KPK dengan Kepolisian RI, laksana cicak dengan buaya. Namun yang bersangkutan meluruskan kembali pernyataannya dihadapan sidang rapat kerja dengan DPR, bahwa kalimat itu sesungguhnya belum selesai dimana pada sisi yang lain, khususnya tentang kewenangan yang ada, justru kepolisian adalah cicak sementara KPK adalah buaya. 
Banyak pihak yang terhenyak dengan pemutaran hasil penyadapan tersebut, dan media masa pun menampilkannya secara live sehingga berhasil menarik perhatian dan menjadi tontonan hampir semua lapisan masyarakat. Belakangan hal ini disadari sebagaimana layaknya reality show yang terbesar dan paling bersejarah di Indonesia. Setelah mendengarkan hasil penyadapan tersebut semua pihak seakan dibukakan matanya tentang adanya suatu konspirasi besar untuk menjatuhkan kinerja KPK, sehingga masyarakat bergerak bersama untuk melawan konspirasi tersebut. Konsekwensi berikutnya tenyata masyarakat menjadi sangat sensitif terhadap setiap kebijakan pemerintah dalam mengatur kerahasiaan berkomunikasi. Kecurigaan tersebut kemudian berimbas kepada kecurigaan terhadap keberadaan RPP Intersepsi yang sebenarnya sudah sejak lama dirancang oleh pemerintah jauh sebelum kasus Cicak vs Buaya tersebut merebak.

Sungguh tak dinyana, akibat ketidakpercayaan terhadap lembaga penegakan hukum (baik Hakim, Polisi, Jaksa dan Pengacara), maka dengan mempertimbangkan kepentingan yang lebih besar, sebahagian ahli justru berpendapat bahwa untuk saat ini, tidak mungkin diperlukan adanya aturan tentang Penyadapan atau Intersepsi karena hanya akan melemahkan kewenangan dari KPK itu sendiri. Hal ini didorong oleh keyakinan bahwa bahwa penyadapan adalah cara yang paling efektif dalam membongkar kasus-kasus tindak pidana korupsi belakangan ini.

Pada sisi yang lain, sebahagian ahli lainnya tetap menyatakan perlu adanya aturan untuk melakukan penyadapan, namun selayaknya aturan tersebut dalam bentuk Undang-Undang bukan dalam bentuk Peraturan Pemerintah, karena setiap pembatasan Hak Azasi Manusia harusnya diatur dalam bentuk Undang-Undang. Kemudian opini juga berkembang bahwa seharusnya penyadapan tidak harus meminta izin pengadilan, karena selain akan terancamnya sisi kerahasiaan dalam melakukan penyapadan, infrastruktur pengadilan di Indonesia tampaknya juga belum siap untuk melakukan prosedural itu.

Lebih jauh lagi, opini semakin berkembang kepada kecurigaan masyarakat kepada pemerintahnya yang mempertanyakan mengapa harus dibuat suatu Pusat Intersepsi, padahal proses intersepsi yang sekarang dilakukan toh sudah berjalan baik dan diyakini telah dilakukan secara ketat oleh masing-masing Aparat Penegak Hukum yang mempunyai kewenangan tersebut.

Dalam perkembangannya kemudian, semua fenomena tersebut di atas berujung kepada upaya judicial review terhadap pasal 31 UU No.11 tahun 2008 tentang Informasi dan Transaksi Elektronik ("UU-ITE") yang dijadikan sebagai dasar pijakan amanat pembentukan RPP Intersepsi tersebut. Pasal tersebut dianggap inkonstitusional oleh Pemohon karena mengamanatkan 
suatu RPP yang seharusnya muatan didalamnya diatur dalam suatu Undangundang. Mencermati semua fenomena tersebut diatas maka akan lebih baik jika kita dapat mengkajinya dengan lebih komperhensif untuk melihat semua permasalahan tersebut secara proporsional.

\section{Apakah Itu Intersepsi dan Apakah Ia Berbeda dengan Penyadapan?}

Sebelum mengulas kaedah hukumnya, maka sebaiknya perlu dipahami terlebih dahulu bagaimana pengertian dan tindakan intersepsi itu.

Setelah dicermati lebih dalam, terlihat bahwa istilah penyadapan yang digunakan dalam bahasa Indonesia dalam konteks berkomunikasi, sebenarnya mengacu kepada istilah wiretapping $^{l 2}$ yang sebenarnya secara historis berawal dari eavesdropping. Kemudian sesuai dengan perkembangan teknologi, berkembang pula pengertian dan istilahnya menjadi interception. Sekilas tampaknya semua hal tersebut tidak mempunyai makna yang berbeda karena ujung-ujungnya adalah suatu tindakan yang tujuannya adalah memperoleh informasi yang dikomunikasikan oleh para pihak. Namun, secara teknis hal tersebut sebenarnya mempunyai pengertian yang sedikit berbeda.

Istilah eavesdropping sebenarnya lebih mengacu kepada tindakan mencuri dengar (listening) dari para pihak yang berbicara secara verbal ataupun oral (aural communication) dimana hal tersebut dapat dilakukan secara manual ataupun dengan menggunakan alat tertentu. Tindakan yang lazim dilakukan adalah dengan cara mendengarkan/menguping secara langsung dari para pihak yang sedang berbicara atau dengan menggunakan suatu alat bantu pendengar (listening device) seperti bug $^{13}$ dan parabolic microphone $e^{14}$ untuk dapat mendengarkan dan/atau merekam pembicaraan tersebut.

${ }^{12}$ Lihat penjelasan pasal 26 UU Tindak Pidana Korupsi dimana secara tegas dalam perundang-undangan dirujuk istilah bahasa inggris wiretapping dalam kurung kurawal terhadap penyadapan.

${ }^{13}$ Bug adalah alat dalam bentuk kecil (mini) agar dapat diletakkan secara tersembunyi baik pada badan maupun untuk diletakkan pada suatu tempat, yang berfungsi untuk memancarkan informasi percakapan dalam suatu ruang kepada suatu perangkat penerima sehingga suatu percakapan dapat didengarkan atau direkam. 
At common law, eavesdropping was considered as nuisance. "Eavesdropping" as William Blackstone defined it, meant to "listen under walls or window, or the eaves of a house, to hearken after discourse, and thereupon to frame slanderous and mischievous tales". ${ }^{15}$

Sementara untuk wiretapping sebenarnya istilah ini lebih mengacu kepada tindakan mencuri dengar komunikasi para pihak yang dilakukan dengan cara menggunakan penambahan alat tertentu atau mencantel ('tapping') saluran kabel komunikasi pada fasilitas jaringan telekomunikasi (wire communication) yang umumnya menggunakan kabel (wire), oleh karena itu disebut wiretapping. Sesuai perkembangan teknologi komunikasi, kemudian komunikasi tidak lagi hanya dilakukan via kabel melainkan juga dapat dilakukan dengan medium nir-kabel (wireless), sehingga tindakan yang sebelumnya lazim dilakukan dengan cara mencantolkan kabel pada saluran komunikasi (tapping) kemudian berkembang dengan cara menghubungkan alat penyadap langsung pada sentral pengalih komunikasi (switching center) yang diselenggarakan oleh Operator Telekomunikasi dengan tujuan mendapatkan direct access kepada sistem yang diselenggarakan oleh suatu Operator Telekomunikasi dan selanjutnya akan melakukan perekaman secara sendiri dan langsung tanpa harus meminta operator yang bersangkutan untuk merekamnya. Hal ini tampaknya semula sangat didominasi dengan paradigma circuit switching sebagaimana yang berlaku dalam suatu jaringan telekomunikasi tetap (Public Switch Telephone Network), namun kemudian akibat teknologi komunikasi yang berkembang dari model circuit switching menjadi packet switching, khususnya seiring dengan perkembangan internet protocol maka berkembang pula istilah baru yakni Intersepsi.

Interception ${ }^{16}$ sebenarnya lebih mengacu kepada tindakan memperoleh informasi dengan cara mencegat ${ }^{17}$ paket informasi yang dikomunikasikan

${ }^{14}$ Parabolic Microphone adalah alat komunikasi seperti parabola yang mempunyai kemampun untuk mendengarkan percakapan dari jarak jauh.

${ }^{15}$ Daniel J. Solove, et.al. "Privacy, Information and Technology", (New York: Aspen Publisher, 2006), hal.64.

${ }^{16}$ Dalam makna kamus intercept adalah kata kerja [Verb] yang berarti: (i) to stop or seize on the way from one place to another, atau (ii) dalam ilmu matematika digunakan sebagai kata benda untuk menandakan adanya suatu perpotongan to mark off or include (part of a line, curve, plane, or surface) between two points or lines. atau dalam bahasa Latin dikenal sebagai intercipere yang berarti to seize before arrival. Sementara menurut European Technical Standard Institute (ETSI), Interception diartikan sebagai action (based on law), performed by a Network Operator/Access Provider/Service Provider of making available 
oleh para pihak secara elektronik (electronic communication). Analoginya adalah sebagaimana layaknya tindakan Aparat Penegak Hukum dalam memeriksa dan menyita surat-menyurat dari pihak pembawa surat (carrier) yang ditujukan kepada tersangka dalam proses penyidikan suatu tindak pidana (lihat pasal 43 s.d 49 UU No. 8 Tahun 1981 tentang KUHAP) ${ }^{18}$.

Dengan mencermati ketiga hal tersebut di atas, jelas terlihat bahwa adanya sedikit perbedaan dalam melakukan tindakan penyadapan ataupun intersepsi tersebut. Namun dalam perkembangannya seiring dengan perkembangan teknologi informasi dan komunikasi yang mengarah kepada packet switching maka Intersepsi kemudian dapat diibaratkan sebagai suatu lingkaran yang lebih besar sementara Penyadapan adalah lingkaran kecil didalamnya. Oleh karena itu, seringkali Intersepi menjadi dipersamakan dengan Penyadapan, demikian pula sebaliknya. Intersepsi menjadi dapat diterjemahkan kepada semua tindakan untuk mencegat atau memperoleh informasi baik dalam bentuk oral maupun elektronik, baik dalam bentuk online maupun offline.

Dilihat dari segi kepentingannya, tindakan intersepsi tersebut tidak hanya bermaksud untuk mendengarkan saja melainkan juga termasuk didalamnya untuk melakukan pembelokan, pengubahan, pencegatan, pemotongan atau bahkan pemutusan dari jalur komunikasi yang semula, sekiranya kepentingan yang lebih besar justru mengharapkan bahwa proses komunikasi tersebut justru jangan sampai terjadi. Sebagai contohnya adalah kepentingan untuk melakukan pencegatan atau pemutusan komunikasi terhadap suatu perangkat telepon genggam sekiranya telepon tersebut dijadikan sebagai alat pemicu ledakan dalam suatu aksi teror. Demikian pula

certain information and providing that information to a Law Enforcement Monitoring Facility (LEMF).

${ }^{18}$ Pasal 43, Penyitaan surat atau tulisan lain dari mereka yang berkewajiban menurut undang-undang untuk merahasiakannya, sepanjang tidak menyangkut rahasia negara, hanya dapat dilakukan atas persetujuan mereka atau atas izin khusus ketua pengadilan negeri setempat kecuali undang-undang menentukan lain. dan pasal 47 ayat (1) Penyidik berhak membuka, memeriksa dan menyita surat lain yang dikirim melalui kantor pos dan. telekemunikasi, jawatan atau perusahaan komunikasi atau pengangkutan jika benda tersebut dicurigai dengan alasan yang kuat mempunyai hubungan dengan perkara pidana yang sedang diperiksa, dengan izin khusus yang diberikan untuk itu dari ketua pengadilan negeri; ayat (2) Untuk kepentingan tersebut penyidik dapat meminta kepada kepala kantor pos dan telekomunikasi, kepala jawatan atau perusahaan komunikasi atau pengangkutan lain untuk menyerahkan kepadanya surat yang dimaksud dan untuk itu harus diberikan surat tanda penerimaan; dan ayat (3) Hal sebagaimana dimaksud dalam ayat (1) dan ayat (2) pasal ini, dapat dilakukan pada semua tingkat pemeriksaan dalam proses peradilan menurut ketentuan yang diatur dalam ayat tersebut. 
halnya apa bila proses komunikasi melalui jaringan komputer ternyata adalah suatu tindakan "denial of service attack" yang dengan mengirimkan pesan 'ping of death' justru malah dimaksudkan untuk mengganggu sistem yang ditujunya.

Dengan kata lain, dalam konteks national security khususnya sebagai upaya pencegahan dan penanggulangan serangan, maka tindakan pencegatan/intersepsi yang dilakukan bukanlah untuk memperoleh informasi guna kepentingan pembuktian di pengadilan, melainkan dilakukan demi melindungi kepentingan yang lebih besar yakni untuk menjaga kelancaran infrastruktur informasi dan komunikasi itu sendiri. Demikian pula halnya dengan aktivitas surveillance ataupun pemantauan (monitoring) terhadap komunikasi yang terjadi yang umumnya dilakukan oleh aparat intelijen negara, hal tersebut dilakukan bukan untuk menjadi bukti di pengadilan melainkan hanya untuk melakukan tindakan pengamatan dan pencegahan.

Sementara dalam konteks intersepsi untuk kepentingan pembuktian di pengadilan (Lawful Intercept), hal ini adalah sebagaimana layaknya penyadapan yang dipahami oleh masyarakat umum. Dimana penyadapan atau intersepsi dilakukan untuk menjadi bukti yang kuat dipengadilan untuk membuktikan bahwa seseorang telah bersalah melakukan tindak pidana. Dalam konteks ini, intersepsi dilakukan untuk melakukan akses dan memperoleh konten informasi yang dikomunikasikan oleh para pihak. Untuk kesahihannya, penegak hukum harus melakukannya secara sah dan tidak melawan hukum demi pengakuannya nanti dimuka pengadilan (admissability).

Perlu kiranya dicermati bahwa meskipun penyadapan ataupun intersepsi dimaksudkan untuk memperoleh konten komunikasi, namun dalam penerapannya tidak selalu harus demikian. Karena secara teknis sebelum kebutuhan akan akses terhadap substansi percakapan (konten) itu diperlukan, penegak hukum biasanya melihat dahulu informasi tentang jasa layanan komunikasi yang ada ${ }^{19}$, khususnya tentang traffic data komunikasi yang dilakukan oleh para pihak. Jika pihak yang diduga ternyata melakukan hubungan komunikasi dengan pihak-pihak yang dicurigai barulah kemudian dilakukan upaya penyadapan terhadap konten komunikasinya. Dalam perkembangannya, ketentuan standar teknis penyadapan ini mengacu kepada European Technical Standard Institute ("ETSI") dan juga American National Standard Institute ("ANSI"). Secara umum, hampir semua negara mengacu

${ }^{19}$ Informasi ttg jasa layanan komunikasi meliputi, antara lain (i) informasi tentang data perlintasan (traffic data), (ii) informasi tentang detail Layanan Komunikasi Elektronik yang digunakan (service in use information), dan (iii) informasi tentang pengguna layanan (subscriber information). 
kepada standar internasional dalam mengatur bagaimana teknis penyadapan atau intersepsi itu dilakukan, demi melindungi privacy warga negara dan mencegah penyalahgunaan oleh aparat penegak hukum.

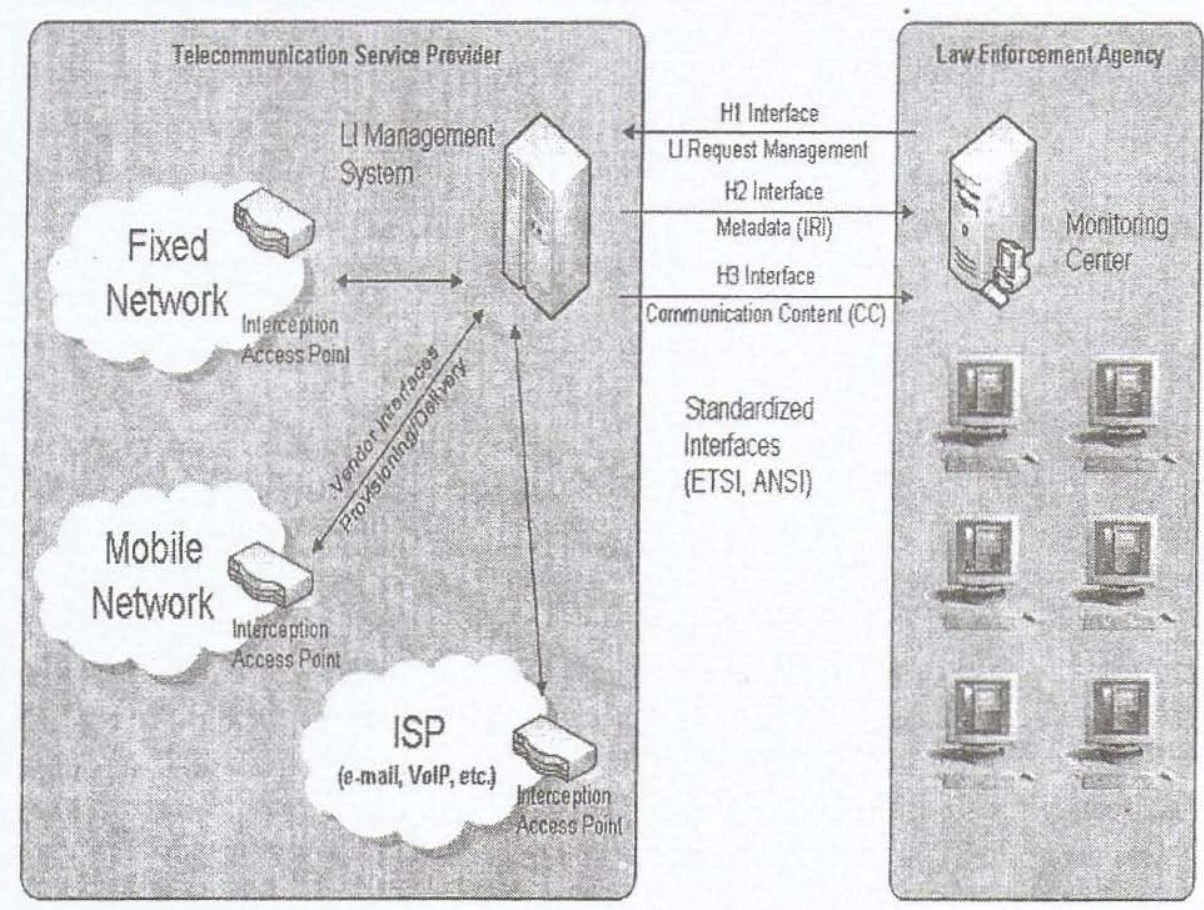

Sebagai catatan awal perlu dicermati bahwa terdapat beberapa pengertian tentang penyadapan, dimana seiring dengan perkembangan teknologi definisi penyadapan telah bergeser kepada pengertian barunya yakni Intersepsi.

1. Pasal 1 angka (18) UU Narkotika, Penyadapan adalah kegiatan atau serangkaian kegiatan penyelidikan dan/atau penyidikan yang dilakukan oleh Penyidik Pejabat Polisi Negara Republik Indonesia dengan cara melakukan penyadapan pembicaraan melalui telepon dan atau alat komunikasi elektronika lainnya. ${ }^{20}$

${ }^{20}$ Pasal ini tetap dipertahankan dalam revisi UU Narkotika tersebut dalam pasal 1 angka (19) UU No.35 Tahun 2009 tentang Narkotika, dimana penyadapan adalah kegiatan atau serangkaian kegiatan penyelidikan atau penyidikan dengan cara menyadap pembicaraan, pesan, informasi, dan/atau jaringan komunikasi yang dilakukan melalui telepon dan/atau alat komunikasi elektronik lainnya. 
2. penjelasan Pasal 40 UU Telekomunikasi, yang dimaksud dengan Penyadapan adalah kegiatan memasang alat atau perangkat tambahan pada jaringan telekomunikasi untuk tujuan mendapatkan informasi dengan cara tidak sah. Pada dasarnya informasi yang dimiliki oleh seseorang adalah hak pribadi yang harus dilindungi sehingga penyadapan harus dilarang.

3. penjelasan pasal 31 ayat (1) UU-ITE, Yang dimaksud dengan "intersepsi atau penyadapan" adalah kegiatan untuk mendengarkan, merekam, membelokkan, mengubah, menghambat, dan/atau mencatat transmisi Informasi Elektronik dan/atau Dokumen Elektronik yang tidak bersifat publik, baik menggunakan jaringan kabel komunikasi maupun jaringan nirkabel, seperti pancaran elektromagnetis atau radio frekuensi.

Dengan memperhatikan perumusan intersepsi di negara lain, maka perkembangan definisi intersepsi yang lebih luas, khususnya dengan kelahiran pasal 31 UU-ITE sebenarnya adalah suatu hal yang lumrah, sebagai contohnya adalah beberapa rumusan sebagai berikut:

1. 18 US Code section 2510 (4), intercept as the aural or other acquisition of the contents of any wire, electronical, or oral communication through the use of any electronic, mechanical or other device.

2. Afrika Selatan, "intercept" means the aural or other acquisition of the contents of any communication through the use of any means, including an interception device, so as to make some or all of the contents of a communication available to a person other than the sender or recipient or intended recipient of that communication, and includes the:

(a) monitoring of any such communication by means of a monitoring device;

(b) viewing, examination or inspection of the contents of any indirect communication; and

(c) diversion of any indirect communication from its intended destination to any other destination.

\section{Kaedah Hukum dalam Intersepsi}

Sesuai norma dasar, adalah hak azasi manusia untuk melakukan hubungan komunikasi dengan pihak lain dan juga merupakan hak azasi manusia terhadap hak kerahasiaan informasi dalam lingkup komunikasi privat antara para pihak. Oleh karena itu pada dasarnya tindakan 
mendengarkan tanpa hak atau mencegat informasi (intersepi) itu sendiri adalah kegiatan yang dilarang oleh Hukum. Hal itu hanya dapat dintervensi oleh hukum demi kepentingan hukum yang lebih besar yakni untuk kepentingan penegakan hukum dalam melindungi ke pentingan masyarakat itu sendiri. (lihat pasal $28 \mathrm{~F}$, pasal $28 \mathrm{G}$ ayat (1), dan pasal $28 \mathrm{~J}$ dalam UUD NRI $1945^{21}$ dan pasal 32 UU HAM). ${ }^{22}$

Sebagaimana layaknya suatu tindakan penggeledahan dan penyitaan (search \& seizure) terhadap orang maupun barang, maka intersepsi adalah suatu upaya paksa terhadap sifat kerahasiaan informasi dalam komunikasi para pihak, dengan cara melakukan akses secara paksa kepada saluran komunikasi dan mengamankan konten percakapan para pihak. Dengan kata lain intersepsi atau penyadapan sebenarnya adalah merupakan upaya melakukan penggeledahan dan penyitaan untuk melakukan akses dan memperoleh informasi yang dikomunikasikan oleh para pihak. Hal tersebut perlu tentunya perlu diatur agar Aparat Penegak Hukum ("APH") dapat menjalankan kewenangannya sesuai dengan prosedur hukum (due process of law) yang baik bukan dengan cara yang sewenang-wenang atau melawan hukum, sebagaimana telah diamanatkan dalam pasal 31 UU-ITE.

${ }^{21}$ Pasal 28F UUD NRI 1945:

Setiap orang berhak untuk berkomunikasi dan memperoleh informasi untuk mengembangkan pribadi dan lingkungan sosialnya, serta berhak untuk mencari, memperoleh, memiliki, menyimpan, mengolah, dan menyampaikan informasi dengan menggunakan segala jenis saluran yang tersedia.

Pasal 28G ayat (1),

Setiap orang berhak atas perlindungan diri pribadi, keluarga, kehormatan, martabat, dan harta benda yang dibawah kekuasaannya, serta berhak atas rasa aman dan perlindungan dari ancaman ketakutan untuk berbuat atau tidak berbuat sesuatu yang merupakan hak asasi. (perubahan kedua), serta

Pasal 28J ayat (1):

Setiap orang wajib menghormati hak asasi manusia orang lain dalam tertib kehidupan bermasyarakat, berbangsa, dan bernegara.

ayat (2)

Dalam menjalankan hak dan kebebasannya, setiap orang wajib tunduk kepada pembatasan yang ditetapkan dengan undangundang dengan maksud sematamata untuk menjamin pengakuan serta penghormatan atas hak kebebasan orang lain dan untuk memenuhi tuntutan yang adil sesuai dengan pertimbangan moral, nilai-nilai agama, keamanan, dan ketertiban umum dalam suatu masyarakat demokratis.

${ }^{22}$ Pasal 32 UU No. 39 tahun 1999 tentang HAM:

Kemerdekaan dan rahasia dalam hubungan surat-menyurat termasuk hubungan komunikasi melalui sarana elektronik tidak boleh diganggu, kecuali atas perintah hakim atau kekuasaan lain yang sah sesuai dengan ketentuan peraturan perundangundangan. 
(1) Setiap Orang dengan sengaja dan tanpa hak atau melawan hukum melakukan intersepsi atau penyadapan atas Informasi Elektronik dan/atau Dokumen Elektronik dalam suatu Komputer dan/atau Sistem Elektronik tertentu milik Orang lain.

(2) Setiap Orang dengan sengaja dan tanpa hak atau melawan hukum melakukan intersepsi atas transmisi Informasi Elektronik dan/atau Dokumen Elektronik yang tidak bersifat publik dari, ke, dan di dalam suatu Komputer dan/atau Sistem Elektronik tertentu milik Orang lain, baik yang tidak menyebabkan perubahan apa pun maupun yang menyebabkan adanya perubahan, penghilangan, dan/atau penghentian Informasi Elektronik dan/atau Dokumen Elektronik yang sedang ditransmisikan.

(3) Kecuali intersepsi sebagaimana dimaksud pada ayat (1) dan ayat (2), intersepsi yang dilakukan dalam rangka penegakan hukum atas permintaan kepolisian, kejaksaan, dan/atau institusi penegak hukum lainnya yang ditetapkan berdasarkan undang-undang.

(4) Ketentuan lebih lanjut mengenai tata cara intersepsi sebagaimana dimaksud pada ayat (3) diatur dengan Peraturan Pemerintah.

Perlu juga untuk dicermati bahwa sebelum adanya UU ITE, proses penyadapan berpayung kepada ketentuan hukum dalam UU Telekomunikasi. Namun, paradigma "penyadapan" dengan "perekaman" informasi sebenarnya adalah dua hal yang berbeda sebagaimana diatur dalam pasal 40 dan pasal 41 UU Telekomunikasi.

\section{Pasal 40}

Setiap orang dilarang melakukan kegiatan penyadapan atas informasi yang disalurkan melalui jaringan telekomunikasi dalam bentuk apapun.

Pasal 41

Dalam rangka pembuktian kebenaran pemakaian fasilitas telekomunikasi atas permintaan pengguna jasa telekomunikasi, penyelenggara jasa telekomunikasi wajib melakukan perekaman pemakaian fasilitas telekomunikasi yang digunakan oleh 
pengguna jasa telekomunikasi, dan dapat melakukan perekaman informasi sesuai dengan peraturan perundang-undangan yang berlaku.

Berdasarkan pasal 40 UU Telekomunikasi tersebut, jelas adanya larangan bagi semua tindakan penyadapan yang dilakukan dalam bentuk apapun, sementara yang diperkenankan oleh pasal 42 UU Telekomunikasi hanyalah tindakan perekaman yang dilakukan oleh Operator atau penyelenggara jaringan atau jasa telekomunikasi itu sendiri berdasarkan atas permintaan institusi penegak hukum. Jadi, pada dasarnya tidak dimungkinkan peluang bagi APH untuk melakukan perekaman secara sendiri dan langsung, sehingga tindakan melakukan 'remote interception' tidak dimungkinkan oleh UU Telekomunikasi. Selanjutnya tindakan kerjasama operator demi kepentingan penegakan hukum tersebut, diamankan sebagai tindakan yang dibenarkan oleh pasal 43 UU Telekomunikasi yang dikatakan sebagai tindakan yang tidak melanggar kewajiban penyelenggara untuk merahasiakan berita dalam komunikasi.

Pasal 42

(1) Penyelenggara jasa telekomunikasi wajib merahasiakan informasi yang dikirim dan/atau diterima oleh pelanggan jasa telekomunikasi melalui jaringan telekomunikasi dan/atau'jasa telekomunikasi yang diselenggarakannya.

(2) Untuk keperluan proses peradilan pidana, penyelenggara jasa telekomunikasi dapat merekam informasi yang dikirim dan/atau diterima oleh penyelenggara jasa telekomunikasi serta dapat memberikan informasi yang diperlukan atas:

a. permintaan tertulis Jaksa Agung dan/atau Kepala Kepolisian Republik Indonesia untuk tindak pidana tertentu;

b. permintaan penyidik untuk tindak pidana tertentu sesuai dengan Undang-undang yang berlaku.

(3) Ketentuan mengenai tata cara permintaan dan pemberian rekaman informasi sebagaimana dimaksud pada ayat (2) diatur dengan Peraturan Pemerintah. 


\section{Pasal 43}

Pemberian rekaman informasi oleh penyelenggara jasa telekomunikasi kepada pengguna jasa telekomunikasi sebagaimana dimaksud dalam Pasal 41 dan untuk kepentingan proses peradilan pidana sebagaimana dimaksud dalam Pasal 42 ayat (2) tidak merupakan pelanggaran Pasal 40.

Oleh karena itu, maka dengan sendirinya turunan ketentuan tersebut di atas adalah bukannya ketentuan tentang tata cara penyadapan oleh APH, melainkan aturan tentang tata cara permintaan dan pemberian rekaman informasi sebagaimana diatur dalam pasal 87 , pasal 88 dan pasal 89 dari PP No.52 Tahun 2000 tentang Penyelenggaraan Telekomunikasi.

\section{Pasal 87}

Dalam hal untuk keperluan proses peradilan pidana, penyelenggara jasa telekomunikasi dapat merekam informasi yang dikirim dan atau diterima oleh penyelenggara jasa telekomunikasi serta dapat memberikan informasi yang diperlukan atas:

a. permintaan tertulis Jaksa Agung dan atau Kepala Kepolisian Republik Indonesia untuk tindak pidana tertentu;

b. permintaan penyidik untuk tindak pidana tertentu sesuai dengan peraturan perundang-undangan yang berlaku.

Pasal 88

Permintaan perekaman informasi sebagaimana dimaksud dalam Pasal 87 disampaikan secara tertulis dan sah kepada penyelenggara jasa telekomunikasi dengan tembusan kepada Menteri.

Pasal 89

(1) Permintaan tertulis perekaman informasi sebagaimana dimaksud dalam Pasal 88 sekurang-kurangnya memuat:

a. obyek yang direkam;

b. masa rekaman; dan 
c. periode waktu laporan hasil rekaman.

(2) Penyelenggara jasa telekomunikasi wajib memenuhi permintaan perekaman informasi sebagaimana dimaksud dalam ayat (1) selambat-lambatnya dalam waktu 1 kali 24 jam terhitung sejak permintaan diterima.

(3) Dalam hal teknis rekaman tidak dimungkinkan, penyelenggara jasa telekomunikasi sebagaimana dimaksud dalam ayat (2) wajib memberitahukan kepada Jaksa Agung, Kepala Kepolisian Republik Indonesia dan atau Penyidik.

(4) Pemberitahuan sebagaimana dimaksud dalam ayat (3) disampaikan selambat-lambatnya 6 (enam) jam setelah diterimanya permintaan sebagaimana dimaksud dalam ayat (1).

(5) Hasil rekaman informasi sebagaimana dimaksud dalam ayat (2) disampaikan secara rahasia kepada Jaksa Agung dan atau Kepala Kepolisian dan atau Penyidik.

Kemudian dalam perkembangannya diterbitkanlah Peraturan Menteri Komunikasi dan Informatika Nomor 11/PER/M.KOMINFO/02/2006 Tahun 2006 tentang Teknis Penyadapan Terhadap Informasi ("Permen 11/2006"). Pada pada dasarnya ketentuan dalam Permen 11/2206 dapat dikatakan bermaksud baik untuk memayungi tindak penyadapan informasi yang sah (lawful interception), namun sayangnya ketentuan tersebut terlihat bertentangan dengan norma yang telah digariskan dalam UU Telekomunikasi yang membedakan secara jelas antara penyadapan dengan perekaman. Hal tersebut dapat dilihat antara lain pada lingkup definisi dan bagaimana mekanisme penyadapan itu dilegalkan oleh menteri.

Dalam pasal 1 angka (7) Permen 11/2006 dinyatakan bahwa Penyadapan Informasi adalah mendengarkan, mencatat, atau merekam suatu pembicaraan yang dilakukan oleh Aparat Penegak Hukum dengan memasang alat atau perangkat tambahan pada jaringan telekomunikasi tanpa sepengetahuan orang yang melakukan pembicaraan atau komunikasi tersebut. Sementara tindakan penyadapan dalam bentuk apapun adalah dilarang dalam pasal 40 UU Telekomunikasi.

Kemudian pada angka (8) dinyatakan bahwa Penegak Hukum yang dimaksud adalah aparat yang diberi kewenangan untuk melakukan penyadapan informasi berdasarkan undang-undang yang memerlukan adanya tindakan penyadapan informasi. Klasifikasi yang diberikan dalam Permen $11 / 2006$ ternyata lebih mempersempit kwalifikasi pada penjelasan pasal 42 ayat (2) huruf (a) UU Telekomunikasi yang tidak hanya memberikan tindak pidana tertentu yang memberikan kewenangan kepada penyidik berdasarkan UU, tetapi juga memperkenankan Jaksa Agung dan Kepala Kepolisian RI 
untuk lingkup tindak pidana tertentu yang ancaman pidana penjaranya 5 (Iima) tahun ke atas, seumur hidup atau mati.

Kemudian pada angka (9) didefinisikan bahwa Penyadapan informasi secara sah (Lawful Interception) adalah kegiatan penyadapan informasi yang dilakukan oleh aparat penegak hukum untuk kepentingan penegakan hukum yang dikendalikan dan hasilnya dikirimkan ke Pusat Pemantauan (Monitoring Center) milik aparat penegak hukum. Sementara ketentuan dalam UU Telekomunikasi hanya memungkinkan untuk meminta bantuan operator tidak melakukannya sendiri secara langsung.

Selanjutnya pada pasal 3 Permen ini dinyatakan bahwa Penyadapan terhadap informasi secara sah (lawful interception) dilaksanakan dengan tujuan untuk keperluan penyelidikan, penyidikan, penuntutan dan peradilan terhadap suatu peristiwa tindak pidana. Sementara dalam penjelasan pasal 42 ayat (2)UU Telekomunikasi hanya menyatakan bahwa yang dimaksud dengan proses peradilan pidana dalam ketentuan ini mencakup penyidikan, penuntutan, dan penyidangan. Pasal 42 tidak menyebutkan tahapan penyelidikan. Jelaslah bahwa pasal 42 UU Telekomunikasi tidak memberikan peluang penyadapan untuk tahapan penyelidikan, melainkan hanya pada tahapan penyidikan dan seterusnya saja.

Selain itu Permen 11/2006 juga memberikan ketentuan tentang alat dan perangkat penyadapan yang sesuai standar internasional (Bab IV), mekanisme teknis penyadapan yang sah (Bab V), keberadaan pusat pemantauan (Bab VI) dan tim pengawas (Bab VII), serta adanya kewajiban untuk jaminan kerahasiaan (Bab VIII) dan pembebanan biaya (Bab IX). Yang paling menarik adalah seakan adanya komitmen bagi para pemikir pada saat itu bahwa penyadapan dapat dilakukan dalam satu gerbang yang dapat dimanfaatkan secara bersama-sama oleh para APH, hal tersebut seakan tercermin dalam pasal 13 Permen 11/2006 bahwa Pusat Pemantauan dapat berfungsi sebagai gerbang komunikasi (gateway) bagi Aparat Penegak Hukum untuk melakukan penyadapan informasi secara sah.

Dari beberapa uraian tersebut di atas, perlu digarisbawahi disini, dari judul peraturannya saja sudah menjadi pertanyaan apakah kewenangan menteri dapat menabrak adanya ketentuan larangan penyadapan dalam UU Telekomunikasi. Terlepas dari adanya iktikad baik untuk memayungi kinerja APH sesuai perkembangan teknologi, khususnya KPK, namun secara normatif sepatutnya tetap disadari bahwa sesungguhnya Permen 11/2006 belumlah suatu payung hukum yang kuat bagi APH untuk melakukan penyadapan dan perekaman secara langsung pada sistem komunikasi (remote interception).

Berdasarkan kenyataan tersebut di atas, maka jelaslah keberadaan RPP Tata Cara Intersepsi sesungguhnya adalah suatu jalan keluar dari adanya 
kerumitan yang terjadi. Pada prakteknya, operator penyelenggara telekomunikasi tentunya menginginkan efisiensi agar perekaman informasi tidak membebankan penggunaan ruang (space) yang dimilikinya, namun tindakan melakukan penyambungan juga jangan sampai mengganggu mutu layanan mereka kepada para pengguna. Operator tentunya tidak keberatan untuk membantu membuka akses namun tentunya hal tersebut tidak berarti mereka harus selalu direpotkan untuk melakukan services satu persatu kepada setiap APH untuk melakukan hubungan akses langsung kedalam sistem mereka secara ekslusif. Selayaknya hal itu dapat dilakukan sesuai standar untuk melakukan Lawful Interception yang baik (LI management system). Pada sisi ini, jelas Operator sesungguhnya berada dalam posisi yang riskan karena rentan akan gugatan Perbuatan Melawan Hukum berdasarkan pasal 1365 KUHPerdata dari para pengguna yang merasa dirugikan karena ternyata justru APH melakukan remote interception akibat adanya perbantuan dari operator penyelenggara telekomunikasi.

Pada sisi yang lain, agar kinerja APH tidak diperkarakan sebagai tindakan yang sewenang-wenang yang malahan dapat menjadi kontraproduktif terhadap mutu penyelenggaraan jaringan dan/atau jasa telekomunikasi kepada publik, dan perolehan informasi elektronik tersebut dapat diakui oleh pengadilan dan terjamin integritas datanya, maka APH juga memerlukan ruang hukum yang memperkenankan mereka untuk melakukan remote interception. Hal tersebut tentunya tidak dapat ditemui dalam paradigama UU Telekomunikasi yang berlaku, hal itu hanya dapat dipayungi oleh peluang yang diberikan oleh UU ITE, seandainya saja para pihak mau membaca peluang tersebut dengan baik secara jernih. Oleh karena itu, ketentuan dalam UU ITE yang mengamanatkan ketentuan teknisnya dalam bentuk PP sesungguhnya telah memberikan peluang bagi para APH untuk saling mempertemukan kepentingannya dengan baik, tidak hanya untuk menyambungkan alat tetapi juga untuk melakukan tindakan-tindakan lain yang diperlukan baik dalam konteks penegakan hukum maupun bahkan demi untuk melakukan perlindungan kepentingan publik yang lebih besar terhadap kelancaran infrastruktur komunikasi dan informasi itu sendiri.

\section{Intersepsi di Beberapa Negara}

Sebagai pembanding, kita perlu juga mempelajari bagaimana dua aliran dasar dalam memandang intersepsi itu, yakni UK Approach ${ }^{23}$ dan US

${ }^{23}$ Lihat Regulation of Investigatory Powers Act 2000 yang mempunyai kategori tindakan utama, yakni tindakan (i) 'interception of the content of a communication' dan (ii) 
Approach. $^{24}$ Dalam pendekatan gaya Inggris, ${ }^{25}$ Intersepsi dapat dilakukan dengan leluasa oleh APH apabila terdapat ancaman terhadap keamanan nasional (national security) baik untuk mencegah maupun mendeteksi suatu tindak pidana, namun hal tersebut tidak dengan serta merta dapat menjadi alat bukti di hadapan pengadilan. Sementara dalam pendekatan gaya AS, adalah sebaliknya, dimana intersepsi tidak mudah untuk dilakukan namun hasilnya dapat menjadi alat bukti dihadapan pengadilan (admissability).

Sesuai perkembangan teknologi informasi dan komunikasi, pengaturan mereka juga telah berubah dimana Wiretapping Act mereka yang tertuang dalam Title III Omnibus Crime Control and Safe Streets Act of 1968 yang semula hanya mengenal oral-communication dan wire-communication kemudian juga telah mengakomodir adanya electronic-communication. Sehingga peraturan perundang-undangannya dapat dikatakan telah mengenal adanya tiga perbedaan tersebut meskipun pada awalnya memperlakukannya dengan pengaturan yang berbeda-beda.

Intercept means the aural acquisition of the contents of any wire or oral communication through the use of any electronic, mechanical, or other device.

Pada dasarnya dalam melakukan intersepsi, APH harus memperhatikan amanat Amandemen Keempat Konstitusi AS, yang melindungi keamanan setiap anggota masyarakat terhadap privasi, barang, maupun hubungan surat menyuratnya dari setiap penggeledahan dan penyitaan yang sewenang-wenang.

The right of the people to be secure in their persons, houses, papers, and effects, against unreasonable searches and seizures, shall not be violated, and no Warrants shall issue, but upon probable cause, supported by Oath or affirmation, and

tindakan 'acqusition and disclosure of communications data.' Tindakan yang pertama adalah tindakan melakukan penyadapan untuk memperoleh konten komunikasi itu sendiri, sedangkan tindakan yang kedua adalah tindakan permintaan dan pemberian data komunikasi para pihak, bukan terhadap konten komunikasinya.

${ }^{24}$ Disampaikan oleh Robert Strange, perwakilan US-DoJ di Indonesia, dalam suatu diskusi tentang Penyapan dan Digital Evidence yang diselenggarakan oleh Ditjen APTEL, Depkominfo.

${ }^{25}$ Lihat Regulation of Investigatory Power Act (RIPA) 2000, dan The Interception of Communications Act 2001 
particularly describing the place to be searched, and the persons or things to be seized.

Berdasarkan perkembangan yurisprudensi, diawali dengan kasus Olmstead vs United States (1928), ${ }^{26}$ Katz vs United States $(1967),{ }^{27}$ sampai dengan kasus Steve Jackson Games vs United States (1994), Warshak vs US $(2006)^{28}$ pada dasarnya kaedah hukum terhadap intersepsi, harus memperhatikan beberapa hal, yakni:

1. reasonable expectation to privacy (perlindungi privasi yang beralasan/wajar);

2. probable cause (ditemukan adanya alasan yang kuat, atau dengan kata lain dapat dikatakan bahwa intersepsi baru dilakukan jika terlebih dahulu diperoleh bukti permulaan yang cukup);

3. legal necessity (adanya suatu kepentingan yang kuat atau memaksa untuk melakukan intersepsi);

4. minimization (intersepsi harus dilakukan secara proporsional, dimana pada prakteknya sebelum diputarkan dihadapan

${ }^{26}$ Dalam kasus Olmstead v. US, mayoritas hakim pada majelis yang menangani perkara berpikir bahwa tindakan mencantol jaringan komunikasi (wiretapping) tidak melanggar privasi si tersangka karena tidak melakukan trespassing kepada rumah si tersangka. Namun Justice Brandeis, seorang hakim pada majelis tersebut melakukan dissenting opinion, karena menurutnya meskipun privasi tidak dinyatakan secara tegas batasannya namun seharusnya dilihat bukan berdasarkan atas tempat melainkan berdasarkan atas kepentingan asasi seseorang, dengan kata lain seharusnya tidak dilihat dalam arti sempit melainkan dilihat dalam arti luas. Dalam perkembangan justru pandangan dari Justice Brandeis yang membuka mata para yuris untuk melihat privasi dalam berkomunikasi harus sesuai dengan perkembangan teknologi telekomunikasi itu sendiri.

${ }^{27}$ Dalam kasus Katz v US, Justice Harlan memberikan standar pemikiran terhadap penerapan perlindungan privasi dalam konteks komunikasi yang dilandasi dengan dua persyaratan, yakni; (i) yang bersangkutan harus memperlihatkan pengharapan perlindungan privasi (expectation to privacy), dan (ii) pengharapan atas privasi tersebut harus dipandang oleh masyarakat sebagai suatu hal yang beralasan atau wajar (reasonable). Dalam menentukan adanya expectation to privacy juga diterapkan 'assumption of risk', dimana sekiranya seseorang berbicara keras2 di telephone maka dengan sendirinya yang bersangkutan telah mengetahui resiko bahwa pembicaraannya akan dapat didengar oleh orang lain, maka konsekwensinya pada kejadian itu yang bersangkutan tidak dapat menyatakan dirinya mempunyai pengharapan untuk dilindungi privasinya.

${ }^{28}$ Dalam kasus Warshak vs US, hakim agung AS berpendapat bahwa email yang tesimpan pada server Internet Service Provider dipersamakan dengan sealed letter sehingga ia dilindungi oleh Amandemen Keempat Konstitusi AS sehingga Pemerintah tidak berhak untuk membukanya kecuali apabila mendapatkan search warrant sebelum melakukan hal tersebut. 
pengadilan, penyidik mengkomunikasikan terlebih dahulu dengan pengacara terdakwa agar melakukan beberapa review sekiranya ada hal dianggap tidak relevan dengan kasus sehingga tidak perlu diperdengarkan dihadapan pengadilan).

Berdasarkan penelitian yang dilakukan oleh SS8 selaku vendor alat penyadap terhadap beberapa produk legislatif di beberapa negara, ditemukan fakta bahwa hampir disemua negara memberikan peluang check and balances untuk melakukan intersepsi tersebut. Tidak hanya negara demokrasi modern, melainkan juga negara yang dikenal bersifat otoriter pun tetap memberikan kewajiban kepada penegak hukumnya untuk meminta izin pengadilan atau setidaknya meminta izin Kejaksaan Agung (contoh: Malaysia, Russia, Singapore, dan lain sebagainya.

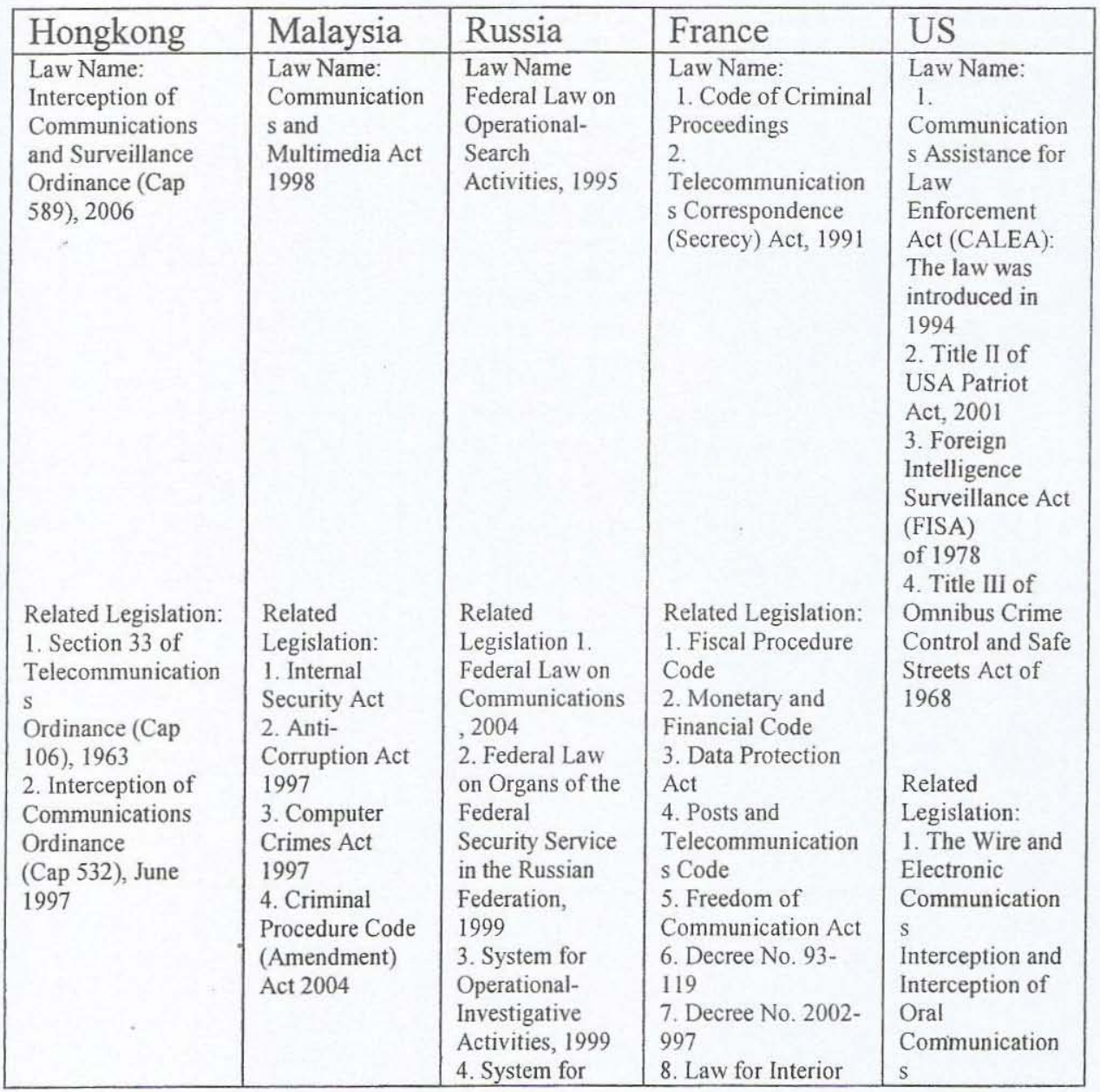




\begin{tabular}{|c|c|c|c|c|}
\hline $\begin{array}{l}\text { Parties Responsible } \\
\text { for Enforcing or } \\
\text { Certifying: } \\
\text { 1. Chief Executive } \\
\text { 2. Chief Justice } \\
\text { 3. Panel Judges } \\
\text { 4. Authorizing } \\
\text { Officer } \\
\text { 5. Commissioner on } \\
\text { Interception of } \\
\text { Communications } \\
\text { and Surveillance }\end{array}$ & $\begin{array}{l}\text { Parties } \\
\text { Responsible for } \\
\text { Enforcing or } \\
\text { Certifying: } \\
\text { 1. Public } \\
\text { Prosecutor } \\
\text { 2. Royal } \\
\text { Malaysia Police } \\
\text { 3. Anti- } \\
\text { Corruption } \\
\text { Agency }\end{array}$ & $\begin{array}{l}\text { Parties } \\
\text { Responsible for } \\
\text { Enforcing or } \\
\text { Certifying } \\
\text { 1. Federal } \\
\text { Security Service } \\
\text { 2. Court of } \\
\text { Justice } \\
\text { 3. Court } \\
\text { 4. Interior } \\
\text { Ministry Police } \\
\text { 5. Parliamentary } \\
\text { and Presidential } \\
\text { Security } \\
\text { Guards } \\
\text { 6. Border Patrol } \\
\text { 7. Customs }\end{array}$ & $\begin{array}{l}\text { Parties Responsible } \\
\text { for } \\
\text { Enforcing or } \\
\text { Certifying: } \\
\text { 1. Court } \\
\text { 2. Ministry of } \\
\text { Interior }\end{array}$ & $\begin{array}{l}\text { Act } \\
\text { 2. The } \\
\text { Electronic } \\
\text { Communication } \\
\text { s Privacy } \\
\text { Act185 } \\
\text { Compliance } \\
\text { Deadlines } \\
\text { Communication } \\
\text { s Assistance for } \\
\text { Law } \\
\text { Enforcement } \\
\text { Act (CALEA) } \\
\text { - Original } \\
\text { deadline of } 25 \\
\text { October } 1998 \\
\text { - Deadline } \\
\text { extended to } 30 \\
\text { June } 2000 \\
\text { - Extension of } \\
\text { deadline from } \\
\text { 30 September } \\
\text { 2001 } \\
\text { to } 19 \text { November } \\
\text { 2001 for } \\
\text { CTIA186 } \\
\text { - ISPs } \\
\text { compliance } \\
\text { deadline of } 14 \\
\text { May } 2007187 \\
\text { Parties } \\
\text { Responsible } \\
\text { for Enforcing or } \\
\text { Certifying: } \\
\text { Predominantly, } \\
\text { the FBI } \\
\text { Impacted Parties } \\
\text { Common } \\
\text { carriers, } \\
\text { facilities-based } \\
\text { broadband } \\
\text { Internet access } \\
\text { providers, and } \\
\text { providers of } \\
\text { interconnected } \\
\text { Voice over } \\
\text { service188 }\end{array}$ \\
\hline
\end{tabular}




\section{Analisis terhadap Pengaturan Intersepsi dalam Beberapa Peraturan Perundang-undangan}

Mencermati bagaimana penyadapan dan intersepsi itu dicantumkan dan diatur dalam beberapa UU di Indonesia, ditemukan adanya keberagaman pengaturan dimana dapat ditarik beberapa catatan, yakni:

- Penyadapan atau intersepsi adalah kegiatan yang dilarang kecuali dilakukan untuk kepentingan penegakan hukum, sedangkan intersepsi yang dilakukan untuk pencegahan demi national security belum ditemukan; ${ }^{29}$

- Kewenangan melakukan penyadapan diberikan oleh UU organik dari suatu tindak pidana tertentu, bukan untuk semua kategori tindak pidana;

- Meskipun beberapa UU menyatakan bahwa Penyadapan dapat dilakukan dalam tahapan penyelidikan, namun kebanyakan UU menyatakan dilakukan setelah memperoleh bukti permulaan yang cukup,

- Dalam melakukan penyadapan terdapat keberagaman jangka waktu maksimum dilakukannya penyadapan (dari waktu 1 bulan, 3 bulan sampai dengan 1 tahun);

- Penyadapan pada dasarnya memerlukan izin pengadilan karena merupakan bentuk upaya paksa dalam mengakses dan memperoleh perekaman informasi, (kecuali KPK yang tidak diamanatkan secara tegas harus meminta izin, namun juga tidak dikecualikan secara tegas dapat dilakukan tanpa harus izin pengadilan);

- Penyadapan atau intersepsi yang dilakukan harus melibatkan peranan pihak operator penyelenggara jaringan atau jasa telekomunikasi untuk melakukan perekaman (lihat UU Telekomunikasi) bukan dilakukan secara langsung (remote interception) oleh aparat penegak hukum yang bersangkutan; ${ }^{30}$

\footnotetext{
${ }^{29}$ Pasal 40 UU Telekomunikasi:
}

Setiap orang dilarang melakukan kegiatan penyadapan atas informasi yang disalurkan melalui jaringan telekomunikasi dalam bentuk apapun.

${ }^{30}$ Pasal 41 UU Telekomunikasi:

Dalam rangka pembuktian kebenaran pemakaian fasilitas telekomunikasi atas permintaan pengguna jasa telekomunikasi, penyelenggara jasa telekomunikasi wajib melakukan perekaman pemakaian fasilitas telekomunikasi yang digunakan oleh pengguna jasa telekomunikasi, dan dapat melakukan perekaman informasi sesuai dengan peraturan perundang-undangan yang berlaku.

Berikutnya dalam penjelasan dinyatakan bahwa rekaman informasi antara lain rekaman percakapan antarpihak yang bertelekomunikasi. 
- Kewajiban tata cara penyadapan hanya diatur lebih teknis dalam UU Telekomunikasi ${ }^{31}$ dan UU ITE ${ }^{32}$ yang selanjutnya diamanatkan akan diatur lebih lanjut dalam PP. Khusus dalam konteks telekomunikasi juga telah terdapat Permen Kominfo No,11 tahun 2006 yang memperkenankan penyadapan secara langsung oleh APH namun dengan melalui gateway dan monitoring center.

- Kewajiban APH dan pihak yang terlibat untuk menjaga kerahasiaan telah ada namun adab melakukan pemutaran intersepsi di persidangan ternyata masih belum spesifik kejelasan aturannya;

- Dengan melihat kepada esensinya bahwa intercept adalah bagian dari upaya penyidikan dalam konteks memperoleh informasi elektronik, maka

${ }^{31}$ Pasal 42 UU Telekomunikasi:

(1) Penyelenggara jasa telekomunikasi wajib merahasiakan informasi yang dikirim dan/atau diterima oleh pelanggan jasa telekomunikasi melalui jaringan telekomunikasi dan/atau jasa telekomunikasi yang diselenggarakannya.

(2) Untuk keperluan proses peradilan pidana, penyelenggara jasa telekomunikasi dapat merekam informasi yang dikirim dan/atau diterima oleh penyelenggara jasa telekomunikasi serta dapat memberikan informasi yang diperlukan atas:

a. permintaan tertulis Jaksa Agung dan/atau Kepala Kepolisian Republik Indonesia untuk tindak pidana tertentu;

b. permintaan penyidik untuk tindak pidana tertentu sesuai dengan Undang-undang yang berlaku. [penjelasan: ancaman $5^{\text {th }}$ ]

(3) Ketentuan mengenai tata cara permintaan dan pemberian rekaman informasi sebagaimana dimaksud pada ayat (2) diatur dengan Peraturan Pemerintah.

${ }^{32}$ Pasal 31 UU ITE:

(1) Setiap Orang dengan sengaja dan tanpa hak atau melawan hukum melakukan intersepsi atau penyadapan atas Informasi Elektronik dan/atau Dokumen Elektronik dalam suatu Komputer dan/atau Sistem Elektronik tertentu milik Orang lain.

(2) Setiap Orang dengan sengaja dan tanpa hak atau melawan hukum melakukan intersepsi atas transmisi Informasi Elektronik dan/atau Dokumen Elektronik yang tidak bersifat publik dari, ke, dan di dalam suatu Komputer dan/atau Sistem Elektronik tertentu milik Orang lain, baik yang tidak menyebabkan perubahan apa pun maupun yang menyebabkan adanya perubahan, penghilangan, dan/atau penghentian Informasi Elektronik dan/atau Dokumen Elektronik yang sedang ditransmisikan.

(3) Kecuali intersepsi sebagaimana dimaksud pada ayat (1) dan ayat (2), intersepsi yang dilakukan dalam rangka penegakan hukum atas permintaan kepolisian, kejaksaan, dan/atau institusi penegak hukum lainnya yang ditetapkan berdasarkan undang-undang.

(4) Ketentuan lebih lanjut mengenai tata cara intersepsi sebagaimana dimaksud pada ayat (3) diatur dengan Peraturan Pemerintah. 
selayaknya harus dilakukan dengan jaminan adanya perlindungan privacy, integritas data sebagaimana telah diamanatkan oleh UU ITE. ${ }^{33}$

Sebagaimana diketahui bahwa sesungguhnya aktivitas penyadapan atau intersepsi adalah merupakan bagian (sub-set) dari aktivitas telekomunikasi pada umumnya sebagai aktivtitas utamanya (main-activities). Dimana aktivitas telekomunikasi itu sendiri adalah adalah setiap pemancaran, pengiriman, dan/atau penerimaan dari setiap informasi dalam bentuk tandatanda, isyarat, tulisan, gambar, suara, dan bunyi melalui sistem kawat, optik, radio, atau sistem elektromagnetik lainnya. Sementara informasi yang dikomunikasikan melalui jaringan sistem telekomunikasi, tentunya bisa bermacam-macam baik dalam bentuk suara, teks, gambar, program komputer, dokumen elektronik, transmisi signal, dan lain sebagainya.

\section{Apakah Diperlukan Suatu UU Tersendiri dalam Mengatur Intersepsi Itu?}

Jika kita mencermati bahwa ternyata beberapa UU telah mengatur normanya secara jelas sebagai larangan pada umumnya dimana pengecualiannya hanya diberikan kepada $\mathrm{APH}$, maka pelaksanaan dari norma tersebut kepada APH, lumrahnya dapat dilakukan dalam bentuk PP. $\mathrm{Hal}$ ini adalah sesuai dengan tertib perancangan peraturan perundang-undang karena PP tidak lagi mengatur publik dan menciptakan norma baru melainkan hanya merupakan pelaksanaan saja. Dengan melihat esensi

${ }^{33}$ Ps.43 UU-ITE

(1) Selain Penyidik Pejabat Polisi Negara Republik Indonesia, Pejabat Pegawai Negeri Sipil tertentu di lingkungan Pemerintah yang lingkup tugas dan tanggung jawabnya di bidang Teknologi Informasi dan Transaksi Elektronik diberi wewenang khusus sebagai penyidik sebagaimana dimaksud dalam Undang-Undang tentang Hukum Acara Pidana untuk melakukan penyidikan tindak pidana di bidang Teknologi Informasi dan Transaksi Elektronik.

(2) Penyidikan di bidang Teknologi Informasi dan Transaksi Elektronik sebagaimana dimaksud pada ayat (1) dilakukan dengan memperhatikan perlindungan terhadap privasi, kerahasiaan, kelancaran layanan publik, integritas data, atau keutuhan data sesuai dengan ketentuan Peraturan Perundang-undangan.

(3) Penggeledahan dan/atau penyitaan terhadap sistem elektronik yang terkait dengan dugaan tindak pidana harus dilakukan atas izin ketua pengadilan negeri setempat.

(4) Dalam melakukan penggeledahan dan/atau penyitaan sebagaimana dimaksud pada ayat (3), penyidik wajib menjaga terpeliharanya kepentingan pelayanan umum. 
amanat putusan MK 2006, maka menurut hemat penulis, amanat tersebut telah dijalankan dengan keberadaan UU ITE itu sendiri yang menyatakan sebagai suatu aktivitas yang dilarang kecuali yang dilakukan oleh APH untuk kepentingan penegakan hukum. Selanjutnya UU ITE mendelegasikan teknis pelaksanaannya dalam bentuk PP, sehingga keberadaan PP tidak dapat dikatakan bertentangan dengan amanat tersebut.

Jika dilihat dari lingkup pengaturan, maka lingkup RPP Intersepsi adalah terhadap komunikasi yang melibatkan peranan dan kewajiban pihak penyelenggara saja, bukan yang dilakukan secara langsung oleh APH sekiranya melakukan penyadapan secara langsung dengan tidak melalui fasilitas penyelenggara. Namun, terhadap oral communication tersebut pada ruang privat tersebut, dengan sendirinya bukan cakupan dari RPP Intersepsi, sehingga sekiranya hal tersebut ingin diatur dalam UU tersendiri, mungkin masih cukup beralasan. Namun tentunya akan menjadi pertanyaan besar apakah sesungguhnya norma dasarnya adalah "larangan" ataukah justru "kebolehan". Jika larangan maka sudah cukup diatur dalam RPP Intersepsi karena yang diatur adalah prosedural bagi APH, namun jika yang ingin dinyatakan adalah "kebolehan" maka UU memberikan aturan kepada masyarakat untuk melakukan penyadapan yang baik dan benar. Dapat dibayangkan bagaimana debat tentang hal itu akan menjadi sangat kompleks, sementara kepentingan APH dalam waktu dekat adalah bagaimana mendapatkan pengakuannya (admissability) dimuka pengadilan dan terhindar dari tuduhan melakukan penyadapan yang melawan hukum.

Oleh karena itu, menurut hemat penulis mendesak aturan untuk dibajukan dalam UU menjadi sangat berlebihan dan cenderung kontraproduktif terhadap kinerja APH itu sendiri, karena sesungguhnya payung legalisasi berdasarkan permen 11/2006 adalah sangat lemah, karena sangat bertentangan dengan norma yang digariskan oleh UU Telekomunikasi. Dapat dikatakan bahwa permen 11 selayaknya tidak mempunyai kekuatan hukum karena administrasi negara tidak mempunyai kewenangan untuk menabrak norma UU. Konsekwensi dari hal tersebut adalah nihilnya kekuatan pembuktian dan terbukanya peluang tuntutan dan gugatan kepada APH karena dalam menjalankan kewenangannya ternyata justru bersifat melawan hukum. Justru sesungguhnya dengan kelahiran pasal 31 UU ITE dan RPP Intersepsi para APH mempunyai peluang untuk segera mendapatkan legalitas yang lebih baik, namun sayangnya justru dipersepsikan keliru oleh sebagian orang.

Selanjutnya dengan memperhatikan UU No.1 Tahun 2006 tentang Kerjasama Timbal Balik dalam Masalah Pidana ("UU MLA"), maka dalam UU MLA jelas dinyatakan bahwa dimungkinkan adanya kerjasama tukar menukar informasi elektronik dan/atau dokumen elektronik, demi 
kepentingan pembuktian tindak pidana. Namun menjadi pertanyaan besar sekiranya standar global menyatakan bahwa intersepsi umumnya dilakukan dengan izin pengadilan sementara di Indonesia tidak menganut seperti itu. Dapat dikatakan bahwa standar global acara pidana atau paling tidak adalah menjadi best practices dalam prosedur acara pidana, dimana terhadap setiap upaya paksa baik terhadap kebebasan orang atau terhadap kepemilikan hartanya harus melibatkan peranan lembaga judisial untuk penetapannya. Sekiranya secara umum, penyadapan atau intersepsi harus meminta izin pengadilan, maka sekiranya ada suatu lembaga penegak hukum yang menyadap tidak harus meminta izin pengadilan, maka selayaknya eksepsi itu harus dilakukan secara tegas, jangan hanya karena interpretasi terhadap lex specialist saja atau karena dalih extra-ordinary crime. Hal tersebut akan menjadi kontraproduktif jika dilhat dari prinsip dan konsistensi normatif perundang-undangan.

\section{Kewenangan Institusi Aparat Penegak Hukum dan Kewenangan Departemen Kominfo serta Urgensi adanya Gerbang Intersepsi Bersama}

Sebagaimana diketahui bahwa beberapa UU telah memberikan kewenangan kepada penyidiknya untuk melakukan penyadapan, seperti antara lain UU Psikotropika, UU Tindak Pidana Terorisme, UU Tindak Pidana Perdagangan Orang, UU Tindak Pidana Korupsi dan UU KPK serta UU Narkotika. Namun pada sisi lain juga terdapat kewenangan administrasi negara pada sektor yang terkait.

Sehubungan dengan itu terdapat kewenangan Kementrian Komunikasi dan Informatika sebagai administrasi negara yang bertanggung jawab terhadap kelancaran penyelenggaraan telekomunikasi di Indonesia

\section{Pasal 4 UU Telekomunikasi}

(1) Telekomunikasi dikuasai oleh Negara dan pembinaannya dilakukan oleh Pemerintah.

(2) Pembinaan telekomunikasi diarahkan untuk meningkatkan penyelenggaraan telekomunikasi yang meliputi penetapan kebijakan, pengaturan, pengawasan, dan pengendalian.

(3) Dalam penetapan kebijakan, pengaturan, pengawasan, dan pengendalian di bidang telekomunikasi, sebagaimana dimaksud pada ayat (2), dilakukan secara menyeluruh dan terpadu dengan memperhatikan pemikiran dan pandangan yang berkembang dalam masyarakat serta perkembangan global. 
Pasal 40 UU-ITE

(1) Pemerintah memfasilitasi pemanfaatan Teknologi Informasi dan Transaksi Elektronik sesuai dengan ketentuan Peraturan Perundang-undangan.

(2) Pemerintah melindungi kepentingan umum dari segala jenis gangguan sebagai akibat penyalahgunaan Informasi Elektronik dan Transaksi Elektronik yang mengganggu ketertiban umum, sesuai dengan ketentuan Peraturan Perundang-undangan.

Bahwa dalam prakteknya, meskipun tidak mengemuka secara gamblang tampaknya penyelenggara telekomunikasi "mengeluh" karena harus berhadapan langsung dengan pihak APH dimana masing-masing ingin diperlakukan khusus (mungkin saja terjadi akibat konflik kepentingan antar institusi APH) yang mengakibatkan terganggunya administrasi dan pelayanan telekomunikasi mereka. Harapan mereka semestinya ada suatu lembaga mediasi agar para APH tidak usah berhubungan langsung dengan para penyelenggara.

Bahwa masing2 APH juga dalam prakteknya menggunakan anggaran negara untuk belanja alat sadap (tanpa pelaporan, registrasi atau uji laik operasi dari Depkominfo) yang seharusnya demi kepentingan nasional dapat dipadukan demi efesiensi. Fenomena ini dikhawatirkan selain karena egosektoral juga karena kepentingan Vendor (vendor driven) dimana tentunya juga akan menjadi masalah berkenaan dengan interoperabilitas nya dengan sistem penyelenggara yang telah ada. Hal tersebut mengakibatkan biaya dan kerepotan bagi penyelenggara telekomunikasi.

Sesuai kewenangan berdasarkan UU Telekomunikasi dan UU ITE, maka demi melindungi kepentingan umum terhadap HAM dan menjaga kelancaran dan mutu penyelenggaraan telekomunikasi, maka Depkominfo berwenang untuk membangun Pusat Penyadapan yang akan digunakan bersama oleh APH sesuai peraturan perundang-undangan yang berlaku. Posisi Depkominfo bukanlah yang melakukan penyadapan, melainkan unsur2 atau perwakilan APH yang berada dalam Pusat Penyadapan itu sendiri demi menjaga kerahasiaannya. Depkominfo hanya memfasilitasi dan melakukan pengawasan kepada APH agar tidak terjadi abuse of power dalam menjalankan kewenangannya.

Oleh karena itu, kewenangan Depkominfo tidak pernah mengerdilkan atau mengebiri kewenangan yang dimiliki oleh setiap APH, melainkan hanya menyatukan infrastruktur dan mengatur tata cara melakukan intersepsi demi melindungi kepentingan umum dari kemungkinan penyalahgunaan kewenangan dan menjaga agar proses dan penggunaan hasil penyadapan 
dapat diterima oleh pengadilan (admissability) dan mencapai tujuannya yakni mempunyai nilai sebagai alat bukti di pengadilan nantinya.

Kontroversi yang dibangun oleh Media Massa, sebenarnya terjadi hanya karena KPK tidak mau ada kewajiban untuk meminta izin pengadilan sebagaima lazimnya yang berlaku dalam persyaratan penyadapan pada umumnya. KPK merasa cukup membuat aturan tata cara menyadap oleh instansinya sendiri dan mendapatkan izin cukup dari Ketua KPK saja tidak harus melibatkan peranan lembaga Yudisial. Padahal dalam UU KPK hanya memuat adanya kewenangan, namun belum ada ketentuan tentang tata cara penyadapan. Sehubungan dengan itu pula telah ada putusan MK terkait kasus KPU 2004 yang mengamanatkan untuk perbaikan UU KPK atau membuat UU lain yang mengatur tentang penyadapan. Namun, dalam pelaksanaannya penyadapan oleh KPK menciptakan permasalahan tersendiri karena menabrak kaedah hukum yang semestinya.

\section{Penutup}

Dari semua uraian tersebut di atas, dapat ditarik beberapa hal penting, yakni:

1. Sesungguhnya intersepsi adalah suatu tindakan yang dilarang karena sesungguhnya melakukan pelanggaran HAM khususnya pelanggaran Privacy dalam berkomunikasi. Hal tersebut hanya dapat dilakukan demi melindungi kepentingan hukum yang lebih besar yakni kepentingan penegakan hukum itu sendiri. Oleh karena itu, selayaknya demi hukum harus dilandasi oleh suatu aturan yang bersifat ketat agar APH tidak dapat melaksanakan intersepsi dengan cara yang sewenang-wenang atau bersifat melawan hukum itu sendiri.

2. sesungguhnya aturan intersepsi yang diamanatkan dalam PP adalah peluang bagi para APH untuk saling berkoordinasi dan mempertemukan kepentingannya dalam menjalankan perintah UU, sehingga selayaknya sudah tepat bentuknya dalam bentuk PP, kecuali jika publik menghendaki aturan intersepsi terhadap komunikasi verbal (oral communication) yang berada dalam ruang privat (contoh: bugging), untuk hal seperti itu tentunya bukanlah merupakan lingkup PP dari UU Telekomunikasi maupun UU ITE itu sendiri. Hal itu mungkin baru relevan jika perlu diatur dalam lingkup UU tersendiri. Namun sudahkah terbayangkan bagaimana lamanya suatu proses pembentukan UU, dan apa 
konsekwensinya jika kinerja yang sekarang ini dilakukan tidak dipayungi dalam bentuk PP

3. Perlunya aturan RPP Intersepi sebenarnya adalah untuk melindungi legalitas kerja para APH itu sendiri agar semua peroleh alat bukti informasi elektroniknya dapat diterima dan dihadirkan sebagai alat bukti di Pengadilan.

4. Keberadaan Pusat Intersepsi Nasional sebagai gerbang (gateway) sesungguhnya sangat diperlukan demi melindungi kepentingan penyelenggaraan telekomunikasi dan/atau penyelenggaraan sistem elektronik yang baik kepada publik. Suatu Pusat Intersepsi Nasional akan menjadikan proses intersepsi oleh para penegak hukum menjadi lebih efisien dan efektif dalam mengakomodir semua perkembangan teknologi informasi dan komunikasi di masa depan.

Dari kesimpulan tersebut diatas, sesungguhnya dapat terlihat bahwa apa yang diupayakan oleh para pihak yang terlibat dalam pembuatan RPP sesungguhnya adalah dalam upaya untuk membuat penyadapan menjadi lebih beradab sesuai best practices penyadapan di hampir semua negara. $\mathrm{Hal}$ ini sebenarnya penting dalam rangka kerjasama timbal balik dalam penegakan hukum pidana (Mutual Legal Assistance) khususnya dalam tukar menukar bukti elektronik yang admissable berdasarkan sistem peradilan pidana yang terpadu (integrated criminal justice system) yang sesungguhnya merupakan kelaziman yang berlaku dalam suatu negara demokratis. Setidaknya RPP tersebut juga perlu dilakukan agar wajah sistem hukum pidana kita menjadi relatif lebih baik lagi ke depan. 


\section{Daftar Pustaka}

Indonesia, Undang-Undang Nomor 5 tahun 1997 tentang Psikotropika. . Undang-Undang Nomor 22 Tahun 1997 tentang Narkotika. . Undang-Undang Nomor 31 Tahun 1999 tentang Pemberantasan Tindak Pidana Korupsi.

Undang-Undang Nomor 3 Tahun 1989 tentang Telekomunikasi menjadi UU Nomor 36 Tahun 1999.

. Undang-Undang Nomor 30 Tahun 2002 tentang Komisi Pemberantasan Tindak Pidana Korupsi.

. Undang-Undang Nomor 18 Tahun 2003 tentang Advokat.

. Undang-Undang Nomor 21 Tahun 2007 tentang Pemberantasan Tindak Pidana Perdagangan Orang.

. Undang-Undang Nomor 11 tahun 2008 tentang Informasi dan Transaksi Elektronik.

. Undang-Undang Nomor 39 tahun 1999 tentang HAM.

PERPU Nomor 1 Tahun 2002 Tentang Pemberantasan Tindak Pidana Terorisme.

Mahkamah Konstitusi Putusan Nomor 006/PUU-I/2003. dan Nomor 012-016-019/PUU-IV/2006.

Peraturan Pemerintah No. 52 Tahun 2000 tentang Penyelenggaraan Telekomunikasi.

Peraturan Menteri Komunikasi dan Informatika Nomor 11/PER/M.KOMINFO/02/2006 Tahun 2006 tentang Teknis Penyadapan Terhadap Informasi.

Kitab Undang-undang Nomor 8 Tahun 1981 tentang Hukum Acara Pidana (Lembaran Negara Tahun 1981 Nomor 76, Tambahan Lembaran Negara Nomor 3209),

Solove, Daniel J., et.al. Privacy, Information and Technology, New York: Aspen Publisher, 2006.

Regulation of Investigatory Powers Act 2000.

Regulation of Investigatory Power Act (RIPA) 2000, dan The Interception of Communications Act 2001. 